
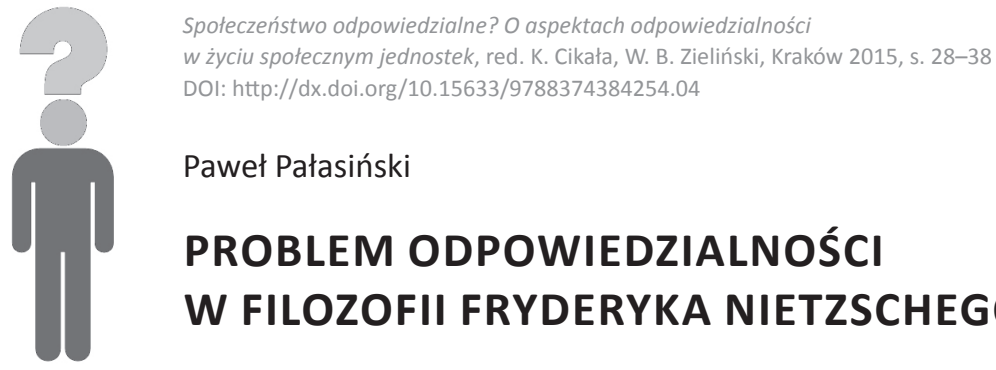

Paweł Pałasiński

\title{
PROBLEM ODPOWIEDZIALNOŚCI W FILOZOFII FRYDERYKA NIETZSCHEGO
}

Głównym celem niniejszej pracy jest ukazanie problemu odpowiedzialności w filozofii Fryderyka Nietzschego oraz obrona tezy mówiącej, iż wyłaniający się po nihilizmie i przemianie wszystkich wartości nadczłowiek - który ma być ideałem dla ludzkości według tego filozofa - jest jednostką odpowiedzialną. Zanim jednak przejdziemy do analizy i omówienia rozważań dotyczących tego problemu w filozofii Nietzscheańskiej, musimy przyjrzeć się dokładniej samemu pojęciu odpowiedzialności. Odpowiedzialność to, jak podaje jeden z popularnych słowników filozoficznych, „konieczność ponoszenia konsekwencji swoich czynów” związana z moralnością bądź prawem ${ }^{1}$ Dalej czytamy, że: „zasada odpowiedzialności zakłada, że sprawca danego czynu był wolny, to znaczy, iż mógł postąpić inaczej"2.

Definicja odpowiedzialności wskazuje zatem, że momentem jej narodzin jest czyn, który uznajemy za wybrany przez nas w sposób wolny. Czyn ten musi być za taki uznany, ponieważ w innym przypadku odpowiedzialność za jego konsekwencje nie będzie odbierana jako nasza. Innymi słowy nasze działanie, za które poczuwamy się odpowiedzialni, to działanie przez nas chciane, nie narzucone przez kogoś czy coś innego.

Możemy wyłonić z omówionej powyżej definicji odpowiedzialności dwa najważniejsze elementy. Pierwszy element wskazuje, że odpowiedzialni jesteśmy za konsekwencje tych naszych czynów, które były przez nas w sposób wolny wybrane. Drugi, że odpowiedzialność łączy się z koniecznością przyjęcia konsekwencji tych czynów. Teraz, gdy już wiemy - przynajmniej w przybliże-

\footnotetext{
1 Por. Odpowiedzialność, [w:] G. Durozoi, A. Roussel, Filozofia. Słownik, tłum. J. Migasiński, J. Niecikowski, Warszawa 1997, s. 193.

2 Tamże.
} 
niu - czym jest i z czym łączy się odpowiedzialność, możemy skupić się na rozważaniach Nietzschego o niej.

Nasze rozważania rozpoczniemy od analizy relacji pomiędzy wolnością a koniecznością na przykładzie dwóch opisanych przez Nietzschego postaci: nadczłowieka i ostatniego człowieka. Dalej przyjrzymy się bliżej Nietzscheańskiemu ujęciu człowieka. Z zagadnieniem tym wiąże się problem czynu oraz jego konsekwencji w kontekście interesującego nas problemu. Poczynione analizy doprowadzą nas do odpowiedzi na główne pytanie niniejszej pracy: czym jest odpowiedzialność dla Nietzschego? Na koniec postaramy się wskazać powody, dla których człowiek miałby być odpowiedzialny według autora Poza dobrem i złem.

\section{Wolność i konieczność}

Nietzsche w swojej książce Tak mówił Zaratustra przedstawia dwie skrajnie różne wizje ludzkiej przyszłości. W pierwszej kolejności filozof przedstawia postać nadczłowieka, w drugiej ostatniego człowieka.

Nadczłowiek jest człowiekiem niedokończonym, ciągle będącym w drodze, ciągle poszukującym, człowiekiem rozwijającym się, który jest „mostem, a nie celem"3. Nadczłowiek uosabia wolność wyboru własnego rozwoju, czyli wyboru swoich czynów ${ }^{4}$. Pomimo tej wolności nadczłowiek nie jest zobowiązany przed nikim, co powoduje, że przyjęcie konsekwencji jego czynów nie jest dla niego konieczne.

Drugą postacią, skrajnie różniącą się od postaci nadczłowieka, jest ostatni człowiek. Ostatni człowiek jest konformistą, nie wybiera swoich czynów, ponieważ wszystkie jego działania są podporządkowane powszechnie obowiązującym standardom mającym zapewnić mu szczęście. Ten drugi rodzaj człowieka oraz idącą wraz z nim przyszłość Nietzsche opisuje w słowach: „Żadnych pasterzy, jedno stado! Każdy chce tego samego, co inni; każdy jest taki sam, jak inni: kto odczuwa inaczej, ten z własnej woli idzie do domu dla obłąkanych"5. Ostatni człowiek nie jest wolny, ponieważ każdy jego czyn jest zdeterminowany przez

3 Por. F. Nietzsche, Tak mówił Zaratustra, tłum. G. Sowiński, Kraków 2005, s. 17.

4 Por. Z Kuderowicz, Nietzsche, Warszawa 1979, s. 138.

5 F. Nietzsche, Tak mówił Zaratustra, dz. cyt., s. 19. 
panujący obyczaj. Jednocześnie trzeba zauważyć, że ostatni człowiek odczuwa swoje postępowanie jako konieczność, która jest ważna, jak pamiętamy, aby przyjąć konsekwencje swoich czynów.

Wydaje się, że nadczłowiek posiada wolność konieczną, aby być odpowiedzialnym. Natomiast ostatni człowiek odczuwa konieczność niezbędną dla przyjęcia konsekwencje swoich czynów. W tym punkcie naszych rozważań uwidacznia się kluczowy dla odpowiedzialności rozdźwięk pomiędzy wolnością a koniecznością, które są dla niej konstytutywne. Owe dwie opisane przez Nietzschego i stojące ze sobą w sprzeczności postawy musimy krótko przeanalizować, ażeby lepiej zrozumieć, czym jest odpowiedzialność.

\subsection{Wolność nadczłowieka a odpowiedzialność}

Nadczłowiek to dla Nietzschego przede wszystkim twórca. To człowiek, który bierze swój los we własne ręce oraz jest niezależny od wszystkiego, co mogłoby ograniczać jego rozwój. Życie nadczłowieka jest jego dziełem. Nadczłowiek jest zatem indywidualistą. Z jednej strony nadczłowiek nie może obwiniać nikogo za kształt swojego życia, gdyż jest jego twórcą i jako taki jest za nie bezwzględnie odpowiedzialny. Z drugiej, nadczłowiek może być odpowiedzialny tylko przed samym sobą, co pozwala mu na bycie nieodpowiedzialnym, gdyż sam może z siebie zrzucić konieczność odpowiadania za własne czyny. Mamy tu zatem do czynienia z problemem odpowiedzialności u nadczłowieka, a dokładniej z problemem odpowiedzialności przy założeniu całkowitej wolności u człowieka.

Nadczłowiek jest całkowicie wolny, nic zatem nie stoi na przeszkodzie, by nadczłowiek nie był świętym, a osobą zdeprawowaną do granic możliwości. Odpowiedzialność nadczłowieka pozostaje w zakresie jego wolności, nie ma tu zatem mowy o konieczności, która pojawiła się w definicji odpowiedzialności omawianej na początku naszych rozważań. Co ważne, nadczłowiek sam tworzy wartości, które są wbrew utylitarnemu rozumieniu dobra i zła, gdyż opierają się na woli mocy ${ }^{6}$. Takie wartości służyć mają jednostce, jej rozwojowi, który polega na ciągłym przezwyciężaniu oporów ${ }^{7}$.

Na podstawie wymienionych tu paru cech nadczłowieka możemy wysunąć przypuszczenie, iż nadczłowiek w dzisiejszych czasach jawiłby się nam jako osoba ekscentryczna, egoistyczna i niestała w poglądach. Ekscentryczna przez swój in-

\footnotetext{
Por. M. Heidegger, Nietzsche, tłum. A. Gniazdowski i in., t. 2, Warszawa 1998-1999, s. 302.
}

Por. F. Nietzsche, Antychrześcijanin, tłum. G. Sowiński, Kraków 1999, s. 38. 
dywidualizm. Egoistyczna przez swoje nastawienie tylko na własny rozwój. Niestałość w poglądach nadczłowieka wynika natomiast z jego ciągłego dążenia do rozwoju, co wymusza zmiany oraz brak jakiejkolwiek konieczności, która zmuszałaby go do przyjęcia jednego moralnego punktu widzenia na całe życie ${ }^{8}$.

\subsection{Ostatni człowiek w okowach konieczności}

Ostatni człowiek w przeciwieństwie do nadczłowieka jest całkowitym przeciwieństwem indywidualisty. Ów człowiek jest częścią grupy, a jego działanie jest całkowicie jej podporządkowane. Można wysunąć przypuszczenie, iż ten ścisły związek ostatniego człowieka z innymi ludźmi jest relacją wzajemnej odpowiedzialności. Ostatni człowiek nie podejmuje żadnych działań, które mogłyby zaszkodzić grupie, dlatego jego działanie można by nazwać odpowiedzialnym. Konsekwencje działań ostatniego człowieka nie mogą powodować zmian, gdyż te mogłyby powodować zagrożenie dla innych. Ostatni człowiek jest zatem ubezwłasnowolniony przez konieczność dbania o dobro innych. Owa wzajemna zależność wszystkich ludzi i wymóg niepowodowania zmian, gdyż mogłyby one zakłócić utopijny stan świata ostatnich ludzi, ma być największym ich wynalazkiem - szczęściem9.

Ostatni człowiek nie jest jednak odpowiedzialny, gdyż nie jest wolny. Każdy czyn ostatniego człowieka jest całkowicie zdeterminowany. Człowiek taki, jako wykonawca zastanego porządku i obyczaju, nie jest odpowiedzialny za nic, bo żaden czyn nie jest jego własnym czynem. Jego własny los jest w rękach masy - czyli nie jest on odpowiedzialny nawet za samego siebie. Za konsekwencje czynu ostatniego człowieka ma odpowiadać grupa, która wyznacza sposoby działania w świecie. Grupa zaś, jak się zdaje, nie jest za nic odpowiedzialna, gdyż odpowiada ona tylko przed samą sobą, co powoduje, że odpowiedzialność staje się bezosobowa - czyli nie dotyczy ona nikogo bezpośrednio.

8 Wola mocy, jak pisze Bogdan Baran, jest tendencją pankosmiczną. Z jednej strony odpowiada ona za wszystko, co tworzy życie, ponieważ jest dążeniem do panowania. Z drugiej strony wola mocy prowadzi do samoprzezwyciężania się, co jest w istocie destrukcją zdobytej władzy, czyli wytworzonego porządku na rzecz tworzenia nowego (por. B. Baran, Postnietzsche. Reaktywacja, Kraków 2003, s. 38-39). W tym względzie nadczłowiek żyjący w zgodzie z naturą, czyli wolą mocy, jest zmienny, gdyż pojawia się u niego dążenie do samoprzezwyciężania się, które może powodować zmiany perspektyw moralnych i poglądów.

9 Nietzsche pisze: „«Wynaleźliśmy szczęście» - mówią ostatni ludzie i mrugają okiem”. Por. F. Nietzsche, Tak mówił Zaratustra, dz. cyt., s. 19. 
W dzisiejszych czasach ludzie tacy jak opisany powyżej ostatni człowiek są uważani za dobrych obywateli, którzy wykonują przydzielone im przez los i państwo obowiązki. Jednocześnie ludzie ci nie ponoszą ryzyka podejmowania własnych decyzji, są podatni na manipulacje, a odpowiedzialnością za swoje wybory zawsze obarczają innych. Przyczyna takiego zachowania ostatniego człowieka tkwi natomiast w nim samym. Człowiek ten nie potrafi być za siebie odpowiedzialny i potrzebuje zwierzchnictwa dla swoich decyzji ${ }^{10}$.

\section{Jak możliwa jest odpowiedzialność u Nietzschego?}

Nadczłowiek, jak wynika z naszych wcześniejszych analiz, jest zmienny, ponieważ ciągle się rozwija. Natomiast ostatni człowiek jest ukończony, jego działania nie powodują żadnej zmiany ani w nim samym, ani w świecie. W naszych rozważaniach szukaliśmy dotychczas odpowiedzi na pytanie, kto jest odpowiedzialny w filozofii Nietzschego. Wydawało się to działaniem prawidłowym, ponieważ odpowiedzialność jest związana z dokonywanym przez kogoś wolnym czynem. Osoba, która nie ma świadomości siebie, swoich czynów oraz konsekwencji swoich działań, nie może być odpowiedzialna ${ }^{11}$. Wolność czynu jest podstawą odpowiedzialności, jednak Nietzsche pisze: „[...] nie ma takiego podścieliska; nie ma żadnego «bytu» poza czynieniem, działaniem, stawaniem się; «czyniciel» jest tylko zmyśleniem do czynienia dodanym - czynność jest wszystkim"12. W świetle przytoczonej wypowiedzi Nietzschego wydaje się, że odpowiedzialność jest niemożliwa, ponieważ nie ma nikogo, kto mógłby dokonywać czynu - istnieje jedynie sam czyn. Pytanie, skąd bierze się w nas poczucie, że to my dokonujemy czynów.

\subsection{Czyn odpowiedzialny}

Nietzsche twierdzi, że człowiek nie „jest”, a „staje się", że podmiot jest domyślony do działania. W konsekwencji skłania nas to do przekonania, iż jesteśmy

10 Por. S. Łojek, Obrona Nietzschego, Kęty 2002, s. 17-18.

11 Przykładowo, polskie prawo kieruje się przesłanką, że tylko osoba świadoma swoich czynów i ich konsekwencji jest odpowiedzialna. Osoby, które tych warunków nie spełniają, mogą zostać uznane za niepoczytalne i zwolnione z odpowiedzialności karnej (art. 31 § $1 \mathrm{KK}$ ).

12 F. Nietzsche, Z genealogii moralności, tłum. L. Staff, Kraków 2003, s. 31. 
raczej wynikiem dziejących się samoistnie czynów. To odwrócenie występujące w filozofii Nietzscheańskiej jest wyjątkowo istotne, jeżeli chcemy zrozumieć zakres odpowiedzialności człowieka. Wydaje się, że jeżeli to nie my panujemy nad naszymi działaniami, a raczej działania stwarzają nas, to odpowiedzialność jest niemożliwa. Jednocześnie musimy przyznać, że mamy poczucie „ja”, że czujemy się owym „czynicielem”.

Nietzsche był świadomy faktu, że w naszym codziennym życiu mamy poczucie bycia sobą. Autor Poza dobrem i złem nie twierdził bowiem, że ludzie takiego poczucia nie posiadają. Nietzsche pisał, iż jest ono konieczne człowiekowi do prawidłowego funkcjonowania, pomimo iż to nasze poczucie „ja” jest rezultatem, a nie podstawą działań ${ }^{13}$. Zdaje się, że dla Nietzschego człowiek nie podejmuje działań w sposób świadomy, a jedynie racjonalizuje dziejący się czyn. Czyny zaś wynikają nie z podmiotu, a z wielości popędów. Nietzsche twierdził, że w człowieku trwa ciągła walka popędów o władzę, czyli o możliwość ich realizacji. Punktem wspólnym dla owej wielości popędów nie jest jedna jaźń, a ciało. Popędy odpowiadają zarówno za czyny, jak i ich racjonalizacje, czyli rozumienie tych czynów przez człowieka.

Co istotne, popędem, który każe człowiekowi uważać się za pana i władcę własnego postępowania, czyli popędem odpowiedzialnym za pojawienie się poczucia „ja”, jest Nietzscheańska wola mocy ${ }^{14}$. Dopiero na kanwie wytworzonej przez wolę mocy iluzji bycia sobą można mieć poczucie odpowiedzialności. Pytanie: jak taka iluzja bycia sobą może być na tyle silna, aby powodowała możliwość dokonywania czynów wolnych? Czy nie jest tak, iż człowiekowi tylko wydaje się, że ich dokonuje? Odpowiedź jest prosta: nie jest istotne, czy człowiek jest rzeczywiście wolny, czy też tylko mu się tak wydaje, ponieważ w Nietzscheańskim świecie stawania się jedyne, na co można liczyć, to iluzja.

Wydaje się, że problemem, który starał się rozwikłać Nietzsche w swojej filozofii, była odpowiedź na pytanie: która iluzja jest dla człowieka pożyteczna? Przykładowo religia dla filozofa była szkodliwa nie dlatego, że jej twierdzenia były nieprawdziwe, ale dlatego, że prowadziła ona według niego do nihilizmu

13 Por. F. Nietzsche, Wola mocy, tłum. K. Drzewiecki, S. Frycz, Kraków 2009, s. 222; por. A. Janaszczyk, Sceptycki element nie-specyficznej teorii poznania F. Nietzschego, [w:] Nietzsche seminarium. Wokół Nietzschego, red. B. Banasiak, P. Pieniążek, t. 1, Toruń 2009, s. 57-58.

14 Por. A. Janaszczyk, Sceptycki element nie-specyficznej teorii poznania Fryderyka Nietzschego, [w:] Nietzsche seminarium. Nietzsche: system czy dywagacje?, red. B. Banasiak, P. Pieniążek, t. 2, Toruń 2010, s. 183. 
i konformizmu ostatniego człowieka. Możemy zatem stwierdzić, że człowiek może dokonywać czynów, które uzna za jego własne wolne czyny. Takie czyny będą wyrazem jego woli mocy, czyli chęci panowania zarówno nad sobą, jak i światem, w którym żyje.

\subsection{Konsekwencje czynów}

Człowiek wierzący w swoją moc kierowania własnymi działaniami to człowiek, który kieruje się wolą mocy. Wydaje się, że przyjęcie konsekwencji czynów wymaga albo ich znajomości, liczenia się z nimi podczas podejmowania działania, albo uznania z góry, że każdy skutek, jaki spowoduje działanie, jest z nim nierozerwalnie związany i jako taki musi być zaakceptowany i uznany za własny.

Problemem w pierwszym przypadku jest sposób, w jaki Nietzsche widzi świat, w którym człowiek żyje. Świat jest stawaniem się, ciągłym zmiennym potokiem zjawisk, w którym nie występuje żadna bezwzględna stałość. Takie ujęcie świata sprawia, że konsekwencje każdego czynu podjętego przez człowieka mogą być inne, niż on przewidział. Jeżeli zaś konsekwencje czynu wykraczają poza to, czego się człowiek spodziewał, to nie czuje się on za nie odpowiedzialny. Winą za takie konsekwencje obarczony zostaje bezosobowy przypadek. Takie działanie może doprowadzić człowieka do przyjmowania tylko pozytywnych konsekwencji swoich czynów. Negatywne konsekwencje byłyby uznawane za nieszczęśliwe przypadki i jako takie wykluczone ze zbioru konsekwencji, za które należy czuć się odpowiedzialnym.

Inaczej byłoby w drugim przypadku, kiedy to człowiek czuje się odpowiedzialny za każdy skutek swoich działań. Postawa taka wydaje się pod paroma względami heroiczna, ponieważ taki człowiek przyjmuje pełną odpowiedzialność za konsekwencje swoich czynów. Nawet więcej, człowiek ten przyjmuje wszystkie, nawet najbardziej niespodziewane konsekwencje. Konsekwencje takie odbiera jako przynależące do niego, akceptuje je jako to, co spowodował i za co jest odpowiedzialny. Wydaje się jednak, że człowiek mający tak wielkie poczucie odpowiedzialności bałby się zrobić cokolwiek, gdyż miałby świadomość, że nie jest w stanie przewidzieć konsekwencji, które musiałby przyjąć.

\subsection{Ucieczka od odpowiedzialności}

Na podstawie naszych dotychczasowych dociekań możemy stwierdzić, że znajdujemy u Nietzschego więcej sposobów na ucieczkę od odpowiedzialności niż dróg prowadzących do niej. Według niemieckiego filozofa człowiek nie jest pod- 
miotem dokonującym wolnych czynów, więc nie może być ani za te czyny, ani za ich konsekwencje odpowiedzialny. Dalej, jak ustaliśmy, konsekwencje czynów są dla człowieka często nieprzewidywalne, co może usuwać z człowieka obowiązek czucia się za nie odpowiedzialnym. Jako że nie odnaleźliśmy w filozofii Nietzschego człowieka odpowiedzialnego, nie pozostaje nam nic innego, jak kontynuować nasze poszukiwania.

\section{Czym jest odpowiedzialność dla Nietzschego?}

Nietzsche pisze o odpowiedzialności w swojej książce $Z$ genealogii moralności:

Dumna świadomość nadzwyczajnego przywileju odpowiedzialności, świadomość tej rzadkiej wolności, tej mocy nad samym sobą i losem, wsiąkła w niego, w głąb jego najskrytszą i stała się instynktem, instynktem dominującym. A jakże nazwie on ten instynkt dominujący? [...] Ten samowładny człowiek zwie go swym sumieniem... ${ }^{15}$.

Odpowiedzialność dla Nietzschego jest w ścisłym związku z wolnością. Człowiek, który może być odpowiedzialny, musi być wpierw wolny, aby uczynić się sobie poddanym, mieć moc nad samym sobą. Widzimy zatem, że człowiek taki musi kierować się instynktem woli mocy. Taki człowiek „przyrzeka”, bierze odpowiedzialność za siebie, za swoje działania i ich skutki, bo jest na tyle silny by się samoograniczyć i dotrzymywać raz danego słowa. Odpowiedzialność dotyczy zatem tych wypadków, w których człowiek podejmuje działanie i zobowiązuje się przyjąć odpowiedzialność za skutki tego działania. Nie mamy już do czynienia z odpowiedzialnością zupełną, a ograniczoną do szczególnych wypadków. Taka odpowiedzialność jest wynikiem indywidualizmu, ponieważ człowiek zobowiązuje się przed sobą, nie ucieka od odpowiedzialności. W tym przypadku sam instynkt woli mocy, który pcha go do tego, aby panować nad sobą, pracuje na rzecz odpowiedzialności. Taka odpowiedzialność dla Nietzschego jest wyrazem siły. Jak można się było tego domyślić, sprawa ta jest jednak bardziej skomplikowana.

Odpowiedzialność jako zdolność prawdziwie wolnego człowieka do przyrzekania przerodziła się z czasem w narzędzie czynienia człowieka „[...] w przód [...] do pewnego stopnia podległym konieczności, jednolitym, równym wśród rów-

15 F. Nietzsche, Z genealogii moralności, dz. cyt., s. 43. 
nych, prawidłowym i przeto obliczalnym"16. Odpowiedzialność, jak przekonuje Nietzsche, przestała wynikać z wewnętrznego przekonania o słuszności jej przyjęcia, a zaczęła kształtować się ze strachu przed konsekwencjami. Co ważne, konsekwencje te nie są bezpośrednio skutkami działań, lecz wynikiem działań masy, która chce odwetu za poniesione szkody ${ }^{17}$.

Należy zauważyć, że zmienia się tu kierunek, z którego bierze się odpowiedzialność. Odpowiedzialność, zamiast znajdować swe źródło w aktywnej chęci panowania nad sobą i światem, zmienia się w reaktywny popęd wynikły z uczucia resentymentu słabych i pokrzywdzonych wobec silnych. Nietzsche w swojej filozofii staje się propagatorem aktywności i afirmacji, która cechuje ludzi twórczych. Właśnie takie jednostki były dla tego filozofa najbardziej wartościowe, ponieważ to one niejako pchają ludzkość do przodu, nie pozwalając jej zastygnąć w żadnej zastanej formie.

\section{Dlaczego człowiek miałby być odpowiedzialny?}

Innym argumentem świadczącym o tym, iż Nietzsche dążył w swojej filozofii do zmiany postawy duchowej ludzkości, jest koncepcja wiecznego powrotu i związana z nią idea amor fati. Pierwsza koncepcja wskazywała człowiekowi sposób myślenia prowadzący do wolnego, ale zarazem niezwykle świadomego czynu ${ }^{18}$. Druga idea miała wieść człowieka do pewnego rodzaju spokoju, spokoju wręcz stoickiego, w którym człowiek akceptuje otaczającą go rzeczywistość pomimo jej nieprzewidywalności, a nawet ze względu na nią. Koncepcja amor fati mówi o sposobie, w jaki człowiek powinien odnosić się do zdarzeń od niego niezależnych. W książce Tak mówił Zaratustra autor pisze: „Tego miłuję, który ze swej cnoty czyni swą skłonność i swe fatum"19. Słowa te każą nam wiązać zatem trzy idee filozofii Nietzscheańskiej, aby móc w pełni odpowiedzieć na pytanie, kim jest człowiek odpowiedzialny w filozofii Fryderyka Nietzschego.

Człowiek odpowiedzialny - nadczłowiek - wykazuje się absolutną wolnością w kwestii dokonywanych wyborów i czynów. Dalej, człowiek ten postępuje we-

\footnotetext{
Tamże, s. 42.

Por. tamże, s. 45.

Por. S. Łojek, Obrona Nietzschego, dz. cyt., s. 194.

19 F. Nietzsche, Tak mówił Zaratustra, dz. cyt., s. 17.
} 
dług maksymy działania wyznaczonej przez wieczny powrót tego samego, mówiącej: „Postępuj tak, abyś zapragnął wiecznego powrotu wszystkiego”20. Następnie ów człowiek działa według zasady amor fati. Trzy idee: nadczłowieka, wiecznego powrotu i amor fati łączą się poprzez jeden cel, który człowiek twórczy wyznacza swojemu życiu. Ów cel staje się swego rodzaju fatum dla człowieka.

Koncepcje wiecznego powrotu i amor fati wspomagają nadczłowieka w jego dążeniu do celu. Dążenie to zaś wymaga odpowiedzialności, ponieważ zakłada ono wolny wybór celu, a dalej ponoszenie jego konsekwencji. Nadczłowiek to osoba, która potrafi narzucić sobie swego rodzaju rygor, dzięki czemu znosi przeciwności losu jako coś, co ją z jednej strony kształtuje i rozwija, z drugiej jako konieczność wynikającą z koncepcji wiecznego powrotu. To sprawia, że nadczłowiek nie neguje otaczającej go rzeczywistości, a afirmuje ją. Afirmuje zatem swoje i wybory, i ich konsekwencje. Swój byt nadczłowiek ujmuje jako swoją własność - domenę swego panowania. Z tego powodu nadczłowiek odbiera konsekwencje swoich czynów jako coś, co do niego należy - za co jest odpowiedzialny.

\section{Podsumowanie}

Nietzsche wskazywał w swojej filozofii jedną drogę - drogę twórcy, niezależnego indywiduum. Droga ta miała wytworzyć jednostkę, która jest w stanie wykazać się wystarczającą siłą, by móc być odpowiedzialną, by móc przyjąć brzemię konieczności odpowiadania za własne czyny. Wyłaniający się z filozofii Nietzscheańskiej obraz człowieka i świata zdaje się pozornie uniemożliwiać bycie odpowiedzialnym. Nietzsche jednak namawia do bycia kimś więcej niż ślepym wyznawcą narzuconego porządku oraz do narzucenia sobie konieczności pomimo faktycznej dowolności wszystkiego, co się staje. Zatem nauką, jaką powinniśmy wynieść z filozofii Nietzscheańskiej, jest to, że tylko człowiek prawdziwie wolny może być odpowiedzialny.

20 S. Łojek, Obrona Nietzschego, dz. cyt., s. 194. 


\section{Bibliografia}

Baran B., Postnietzsche. Reaktywacja, Kraków 2003.

Durozoi G., Roussel A., Filozofia słownik, tłum. J. Migasiński, J. Niecikowski, Warszawa 1997.

Heidegger M., Nietzsche, tłum. A. Gniazdowski i in., t. 2, Warszawa 1998-1999.

Janaszczyk A., Sceptycki element nie-specyficznej teorii poznania F. Nietzschego, [w:] Nietzsche seminarium. Wokół Nietzschego, red. B. Banasiak, P. Pieniążek, t. 1, Toruń 2009.

Janaszczyk A., Sceptycki element nie-specyficznej teorii poznania Fryderyka Nietzschego, [w:] Nietzsche seminarium. Nietzsche: system czy dywagacje?, red. B. Banasiak, P. Pieniążek, t. 2, Toruń 2010.

Kuderowicz Z., Nietzsche, Warszawa 1979.

Łojek S., Obrona Nietzschego, Kęty 2002.

Nietzsche F., Antychrześcijanin, tłum. G. Sowiński, Kraków 1999.

Nietzsche F., Tak mówił Zaratustra, tłum. G. Sowiński, Kraków 2005.

Nietzsche F., Wola mocy, tłum. K. Drzewiecki, S. Frycz, Kraków 2009.

Nietzsche F., Z genealogii moralności, tłum. L. Staff, Kraków 2003. 